\title{
IMPROVING STUDENTS' READING COMPREHENSION OF RECOUNT TEXT BY USING THINK-PAIR-SHARE (TPS) TECHNIQUE
}

\author{
Radhita Vidya ${ }^{1}$, Annisa Nuraini ${ }^{2}$, Odo Fadloeli ${ }^{3}$, \\ ${ }^{1}$ IKIP SILIWANGI \\ ${ }^{2}$ IKIP SILIWANGI \\ ${ }^{3}$ IKIP SILIWANGI \\ ${ }^{1}$ radhita.212@yahoo.com, ${ }^{2}$ annisanuraini44@gmail.com, ${ }^{3}$ odofadloeli@ upi.edu,
}

\begin{abstract}
The aims of this research is to improve reading comprehension of the eighth-grade students using thinkpair-share technique. The researchers applying this technique is to make students actively learn in classthrough pair discussions and sharing information with their friends. The researchers used a classroom action research (CAR) method, this research has been carried out in three cycles to achieve students improvement in reading comprehension. The mean scores of students in the first cycle is 57.60, in the second cycle is 64.67 , and in the third cycle is 77.20. The mean scores of the three cycles prove that the think-pair-share technique has succeeded in improving students' reading comprehension of recount text.
\end{abstract}

Keywords: Think-Pair-Share, Reading comprehension ,Recount text

\section{INTRODUCTION}

Reading is one of the four language skills that should be learned by junior high school students'. Reading is a mean of communication, sharing ideas and information, one of the most important skills because reading has become parts of daily lives. One aspect of reading will be a focus on reading comprehension. Based on the fact, when students' reading recount text, they often argue that it is difficult for them to comprehend, and to know the meaning of the words in recount text. Confirming the fact, based on English teacher in junior high school found that the problem is students just read the recount text without comprehending the meaning of the words.

Recount text is a type of genre which has been taught in junior high school at eight grade students. Recount "tells what happened". It retells past event for the purpose of informing or entertaining. It could be someone's experiences, someone's life in the past, the history of something. According to (Anderson, 2003) said that, "Recount is a piece of text that retells past events, usually in the order in which they occurred. The purpose is to provide the audience with a description of what occurred and when it occured". It means that recount text is a type of reading text that retells and provides information on an event in the past in sequence.

Recount text has the generic structure, according to (Utami, 2012) the generic structure of recount text begin with an orientation, the orientation section is an introduction of the text to be discussed because in the orientation it tells who is involved in the story, what happened, where the event occurred, and the time when the event occurred. In the middle there is an event, which is the core of the story. This section tell everything that happened in sequence from the beginning to the end. And the last there are re-orientation, re-orientation section that contains 
conclusions from the contents of the story, or it can also be a personal opinion of the story. This re-orientation is similar to the end or closing of the story.

Based on the description above, the researcher was interested in improving the students' reading comprehension of recount text using the good techniques in the learning process, because the good techniques can make the learning process effective and make students improve the achievement. Think-pair-share is one of the techniques that can be used by the English teachers in learning reading comprehension. According to (Huda, 2011) think-pair-share techniques was developed by experts in recent years. Think-pair-share is a simple learning technique where when the teacher delivers a lesson in class, students sit in pairs between their teams to answer assigned questions.

The basis of this technique is to make students become active in the teaching and learning process by pairing and discussing with friends in their class. Besides that the learning process will be more interesting and fun (Kagan \& Kagan, 2009). It will have a positive impact on the students in understanding the subject. Think-pair-share techniques is an effective way to create class discussion patterns. Assuming that discussion requires setting and controlling the class as a whole, and the steps used in think-pair-share give students more time to think about giving ideas and exchanging ideas.

(Kagan \& Kagan, 2009)stated there are five steps in think-pair-share techniques, they are organizing students into pairs, posing the topic or a question, giving time to students to think, the teacher asks students to discuss with their partners and share their ideas with each other, calling on several students to share ideas with their friends. (Kagan \& Miguel, 2009) also mentions some benefits of think-pair-share technique, they are, when students are given time to think, students' abilities increase, students are actively engaged in thinking becomes more focused when it is discussed with a partner, students think more critically after they are given the opportunity to discuss and reflect on the topic of learning, no specific materials are needed for this learning technique, it becomes easier to apply in learning.

\section{METHOD}

The researcher used a type of classroom action research (CAR) to support the process of improving students' reading comprehension of recount text by using think-pair-share techniques. (Arikunto, 2008) stated that classroom action research is a research done by a researcher in collaboration with a teacher in their classroom of teaching and the purpose is to find a way for the teacher to have improvement in their teaching. Based on the description, the researchers conclude that classrooom action research is a process to solve the problem in teaching process in the classroom. This research was conducted on eighth-grade students of

SMP Negeri 11 Kota Cimahi consisting of 30 students as research subjects. (Widi, 2010)stated that classroom action research consisted of four components, namely: planning, action, observation, and reflection. In this research, researchers used several procedures, including planning, acting, observing, and reflecting.

The researchers also used three data collection tools to obtain the data, namely:

a. Test

The test consists of 25 multiple choice items related to the recount text. Student scores are included in the table score to be analyzed. This is a way to get the mean score. Students can achieve success indicators which means that the teacher can help students improve their reading comprehension of recount text with the use of think-pair-share.

The researcher calculating the result of students reading test as follows: 


$$
\text { Score }=\frac{\text { Students }{ }^{\prime} \text { correct answer }}{\text { total number of items }} \times 100 \text { (Rolume 2, No. 2, March } 2019 \text { pp 146-155 }
$$

The researcher will describe the analysis of data taken from the results of the student's reading test. The mean score of each student is calculated using the formula below:

$$
m=\frac{\sum x}{N}
$$

Note: $\mathrm{m}=$ the students mean score

$\sum x=$ the sum of students score

$\mathrm{N}=$ the number of students

(Mertler, 2006)

The mean score was classified into the following table:

Table 1. Criteria Mean Score

\begin{tabular}{cc}
\hline Range & Qualification \\
\hline $80-100$ & Good to excellent \\
$66-79$ & Average to good \\
$50-65$ & Poor to average \\
$0-49$ & Poor
\end{tabular}

(Heaton, 2008)

Based on the determination of the KKM (Kriteria Ketuntasan Minimum) score at eightgrade students SMP Negeri 11 Kota cimahi is 70. The mean score is supported by the daily activities they produce. Students can get a significant increase if students respond well to the learning strategies applied by the researchers.

b. Observation sheet

Observation sheet is used to observe students during teaching activities. This observation sheet is also used to obtain student activity data during teaching and learning activities using think-pair-share strategy

c. Field notes

Field notes are notes that are made when learning activities are applied. The researcher will analyze the data taken from the results of the student worksheet.

\section{RESULTS AND DISCUSSION}

\section{Results}

This research was conducted in three cycles. The researcher applied reading comprehension in recount text material using the think-pair-share technique, the teacher conducted the research in the first cycle based on the problems in the eighth-grade of SMP Negeri 11 Kota Cimahi, 
among others: students had difficulty identifying the generic structure of the recount text, students had difficulties in comprehending the information in recount texts.

After collecting the student tasks, the researcher calculates the students' scores in order to get the mean score. The results of the first cycle are not really good, the mean score in the first cycle is 57,60. It means that the researcher must be better in the next cycle because the aim of the researcher is to reach the mean score of 70 . The results of the first cycle can be seen from the table below:

Table 2. Students score in cycle 1

\begin{tabular}{|c|c|}
\hline Students & Score \\
\hline 1 & 60 \\
\hline 2 & 52 \\
\hline 3 & 56 \\
\hline 4 & 60 \\
\hline 5 & 64 \\
\hline 6 & 52 \\
\hline 7 & 56 \\
\hline 8 & 60 \\
\hline 9 & 52 \\
\hline 10 & 52 \\
\hline 11 & 52 \\
\hline 12 & 56 \\
\hline 13 & 52 \\
\hline 14 & 56 \\
\hline 15 & 56 \\
\hline 16 & 72 \\
\hline 17 & 52 \\
\hline 18 & 72 \\
\hline 19 & 56 \\
\hline 20 & 72 \\
\hline 21 & 56 \\
\hline 22 & 56 \\
\hline 23 & 56 \\
\hline
\end{tabular}




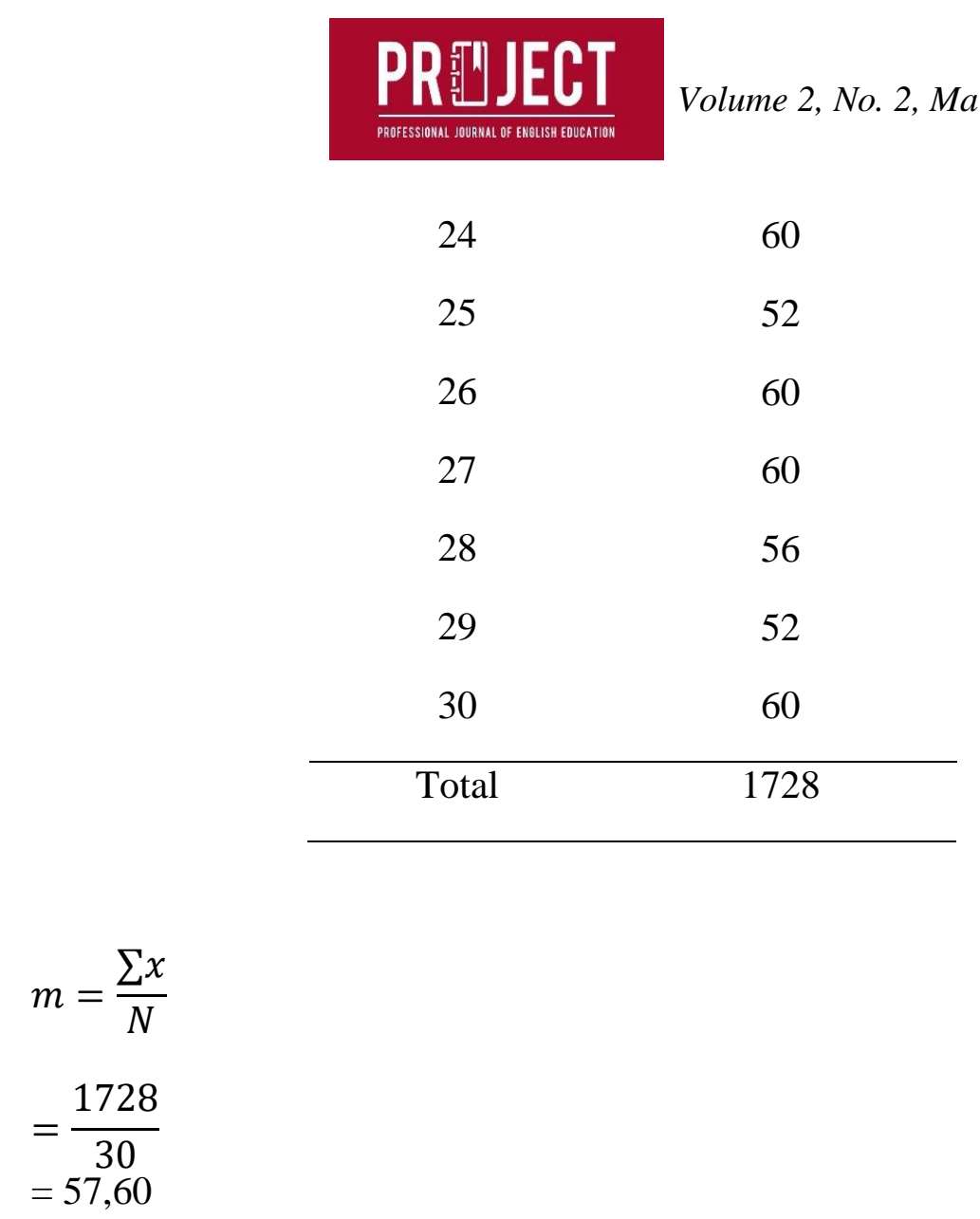

Regarding the first cycle, the problem that must be solved in the second cycle is that students are still confused in determining the generic structure of the recount text, students are still difficult to find information in the recount text, students are still less motivated to read recount texts, students are not familiar with think-pair-share technique.

Based on the problem above, the researcher conducted the second cycle. The researcher explains think-pair-share technique in recount text so students are motivated and accustomed to the learning process. The results of the second cycle are still not good because the mean of students score is 64,67 . The results of the second cycle can be seen from the table below:

Table 3. Students score in cycle II

\begin{tabular}{cc}
\hline Students & Score \\
\hline 1 & 64 \\
2 & 60 \\
3 & 56 \\
4 & 60 \\
5 & 76 \\
6 & 60 \\
7 & 60 \\
8 & 60
\end{tabular}




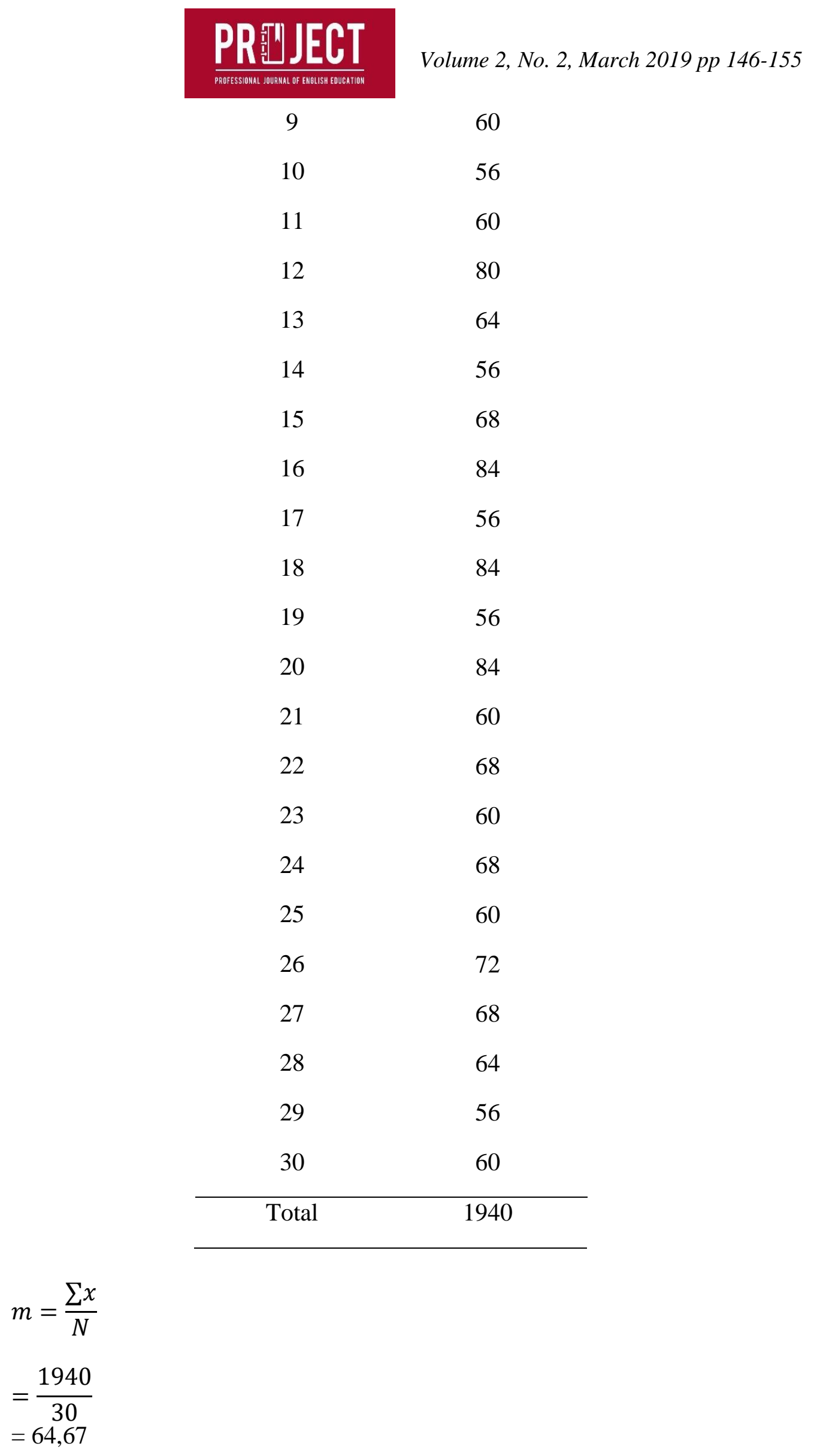

Regarding the second cycle, the problem that must be addressed in the second cycle is that students are able to understand the language feature in recount texts, students are confused in 
determining main ideas in recount texts, students' motivation to read becomes more increasing, students become familiar with think-pair-share technique.

Based on the mean score in the first and second cycles, the researcher conducted the third cycle, then the researchers checks the students' answers and gives a score on the student's work results. The results are good because it can be seen from the number of students increase in their scores and the mean score of students is 77,20 . The results of the third cycle can be seen from the table below:

Table 4. Students score in cycle III

\begin{tabular}{|c|c|}
\hline Students & Score \\
\hline 1 & 80 \\
\hline 2 & 72 \\
\hline 3 & 76 \\
\hline 4 & 72 \\
\hline 5 & 84 \\
\hline 6 & 80 \\
\hline 7 & 72 \\
\hline 8 & 76 \\
\hline 9 & 72 \\
\hline 10 & 80 \\
\hline 11 & 76 \\
\hline 12 & 84 \\
\hline 13 & 72 \\
\hline 14 & 80 \\
\hline 15 & 80 \\
\hline 16 & 84 \\
\hline 17 & 76 \\
\hline 18 & 80 \\
\hline 19 & 72 \\
\hline 20 & 84 \\
\hline 21 & 80 \\
\hline 22 & 80 \\
\hline
\end{tabular}




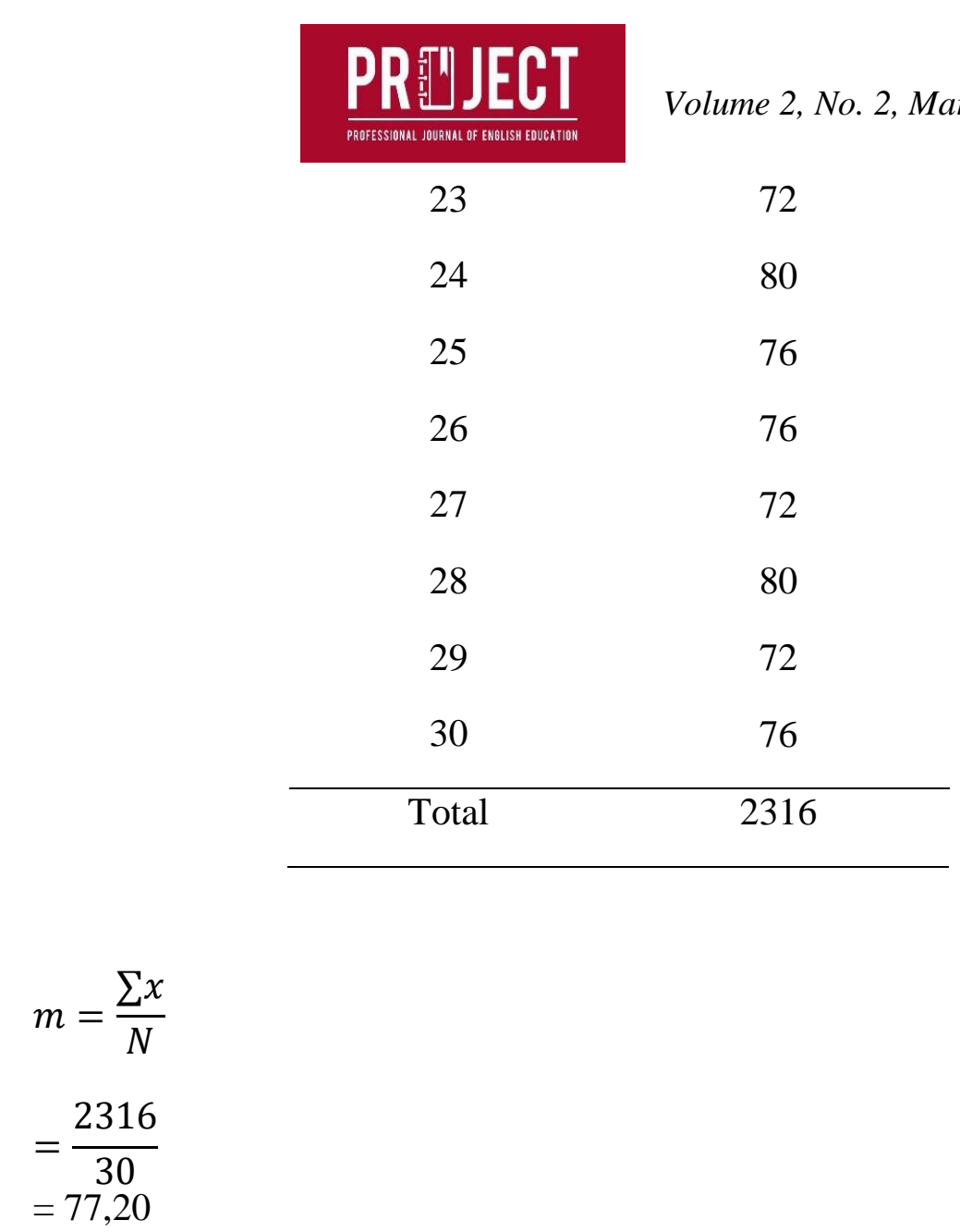

Based on the findings, the learning process in the third cycle is better than the first and second cycles. Students' mean scores increase in reading comprehension of recount text. The cycle can be stopped because the average score shows more than $70 \mathrm{KKM}$ values. That means the research has succeeded and the cycle can be stopped.

\section{Discussion}

This classroom action research is carried out in three cycles. There are planning, action, observation and reflection in each cycle. Students faced difficulties in reading comprehension of recount text including students find it difficult to understand detailed information, students face difficulties in determining the generic structure contained in recount text, and students face difficulties in determining the main ideas in recount text.

In the first cycle, students face difficulties in determining the generic structure and detailed information contained in recount text. In the second cycle, students can determine the generic structure of the recount text but students are still difficult to find detailed information in recount text. In the third cycle, researchers actively monitor student discussions in each group, students first answer their own questions then students pair up with friends to get information or find the most correct answers. Students show enthusiasm with good teamwork and students become more active seen, they enjoy the learning recount text using think-pair-share technique.

Students can complete the task given by researchers, researchers also provide opportunities for students to exchange thoughts during the learning process. The researcher stops the class action because the data shows the achievement score has been successful. The findings show that the average value of students at the first cycle is 57,60. It is qualified "poor to average". That means researchers must prepare better for the next cycle. The average value of students at the second cycle is 64,67. It is qualified "poor to average". And at the third cycle is 77,20. It is qualified "average to good". 
Percentage of achievement score for each student was presented as follows: Based on the score of KKM (Kriteria Ketuntasan Minimum) in English subject at SMP Negeri 11 Kota Cimahi $100 \%$ of children graduated from the KKM score. Think-pair-share technique makes students active in learning and students can learn in pairs. Students can also share knowledge with their group friends through class discussions

In conclusion, the research findings are in accordance with what the researchers expected. Reading comprehension in recount text increases using the think-pair-share technique. In the teaching and learning process, students are not only seen reading to answer questions but they show interest and motivation to learn in reading comprehension of recount text.

\section{CONCLUSION}

\section{Conclusion}

Reading comprehension of the eighth-grade students in SMP Negeri 11 Kota Cimahi has increased with the use of think-pair-share techniques. The findings indicate that the mean score of students in reading comprehension is 57,60, 64,67 and 77,20. Students work in pairs and groups. Think-pair-share technique also allows students to express their thoughts, opinions, and information obtained from recount texts to their friends. At the first cycle, there were no good results, the results began to appear when the cycle was carried out three times.

In conclusion think-pair-share (TPS) technique is proven to be able to help students improve their reading comprehension in recount text.

\section{Suggestion}

Think-pair-share technique is recommended for reading comprehension. Think-pair-share can help students understand the generic structure, determine main ideas and understand detailed information contained in recount text. The teacher must guide students in understanding a text and provide opportunities for students to share ideas or difficulties faced as input for teachers to be better teaching in the future.

\section{ACKNOWLEDGMENTS}

The writer would like to thank to Allah SWT for giving me the opportunity to work on this journal, also to the IKIP Siliwangi which has been the facilitator of this journal, also to Dr. H. Odo Fadloeli, MA and Aseptiana Parmawati, M.Pd who have guided in this journal. And also to the SMP Negeri 11 Kota Cimahi which has allowed me to carry out this journal research.

\section{REFERENCES}

Anderson, Ma. K. A. (2003). Text Type in English 3. South Yarra: McMillan Education PTY LTD.

Arikunto, S. (2008). Penelitian Tindakan KElas. Jakarta: Bumi Aksara.

Heaton. (2008). Using English in the Classroom. Singapore: longman Singapore Publisher.

Huda, M. (2011). Cooperative Learning Metode, Teknik, Struktur dan Model Penerapan. yogyakarta: pustaka belajar.

Kagan, S., \& Kagan, M. (2009). Kagan Cooperative Learning. California: Kagan Publisher.

Mertler, C. A. (2006). Action Research: Teacher as Reasearcher in the Classroom. California: SAGE Publication Inc.

Rusdiansah. (2010). The Effectiveness of Directed Reading Activity Method in Teaching 
Reading to The Second Year Students of SMA Muhammadyah 6 Makasar English Education Department. (20401106029), 1-75. Retrieved from http://repositori.uinalauddin.ac.id/2565/1/RUSDI SKRIPSI UIN.PDF

Utami, A. B. (2012). Improving Students' Writing Skills on Recount Text Through

Collaborative Writing Technique (Classroom Action Research on Grade Eight of SMP N 2 Sentolo in the Academic Year of 2011/2012). 1-229. Retrieved from http://eprints.uny.ac.id/38716/1/Amrih Bekti Utami_07202244062.pdf

Widi, R. K. (2010). Asas Metodologi Penelitian. Yogyakarta: Graha Ilmu. 